\title{
Tyler Wentzell, Not for King or Country: Edward Cecil-Smith, the Communist Party of Canada, and the Spanish Civil War (Toronto: University of Toronto Press, 2020) 368 pp. Cloth, \$95.00.
}

Tyler Wentzell describes his book, Not for King or Country: Edward Cecil-Smith, The Communist Party of Canada, and the Spanish Civil War, as a biography. Cecil-Smith commanded the nominally Canadian Mackenzie-Papineau Battalion of the XVth International Brigade, one of several internationally recruited brigades that fought fascism during the Spanish Civil War. Wentzell's book grew out of his question, "Why did nearly 1,700 Canadians, among perhaps 45,000 non-Spaniards, leave their homes to fight in a war in which their country was not a party?" The usual response of "for king and country" was, in the author's words, "clearly an inadequate explanation" (3).

Wentzell begins by chronicling Cecil-Smith's extraordinary youth. Born in China to missionary parents, his mother Australian and his father British, he was educated at the prestigious Chefoo boarding school. Moving to Shanghai in 1917, he volunteered in the Shanghai Volunteer Corps, a paramilitary body organized to protect foreigners and their property (15). Immigrating to Canada in 1919 and settling in Toronto, he enlisted in the militia, attaining the rank of Sergeant-Major by the age of 25, a very young age for a senior noncommissioned officer. As a reporter in 1931, he witnessed police savagely beat Communist demonstrators at Queen's Park. His shock and outrage combined with his newfound friendship with Young Communist League organizer Oscar Ryan to facilitate his movement into radical circles (22-25).

That same year, police arrested the top eight leaders of the Communist Party under the draconian Section 98 of the Criminal Code, which effectively outlawed membership in the Communist Party. Cecil-Smith joined the Party and threw himself into a life of activism, writing articles for the Party's paper The Worker and taking on leadership roles in numerous front organizations such as the Canadian Labour Defense League (CLDL), the Progressive Arts Club (PAC), and the Workers' Experimental Theatre (WET). In addition, he edited the PAC's magazine Masses. (34-41) Perhaps his most significant work during this time was co-writing and performing in the play Eight Men Speak, an agitprop that highlighted the brutality of the Canadian state in suppressing the Communist Party. Authorities banned it after its first performance on 4 December 1933 (58).

Following the Comintern's adoption of the popular front strategy, the Party abandoned its cultural work and soon took up the cause of Spain, recruiting approximately 1,700 Canadians, including Cecil-Smith for the International Brigades. 
In some ways he was typical of Canadian volunteers. He was 34 . The average age was 32. Like 78 percent of volunteers, he had been born outside Canada. Also, like three quarters of his comrades he was a member of the Communist Party. He differed from many in terms of ethnicity and class. He was a middle-class Anglo-Saxon among a host of workers, many of whom spoke English as their second language. Also, unlike his comrades, he had substantial military experience, albeit none in combat. Initially commissioned a teniente in the George Washington Battalion, he transferred to the newly-formed Mackenzie-Papineau or 'Mac-Paps', after recovering from wounds received in the Brunete campaign in June. He soon took command of the battalion as mayor and led it for most of its existence until he was wounded a second time in September, at which point he was removed from the line. Spanish Premier Juan Negrín disbanded the International Brigades the following month. By the time Madrid fell in April 1939, most Canadians, including Cecil-Smith, were back in Canada (200).

The dénouement of Cecil-Smith's political life began upon his return to Canada. The Party put him to work writing a history of the battalion. He finished a draft of the introduction, then abandoned the project, in what appears to be a response to the Party "meddling" in the process (201). By 19 September 1939, he was back in a Canadian Army uniform and ready to fight fascists once more. An extensive campaign by the RCMP aimed at keeping veterans of Spain out of the armed forces, however, resulted in Cecil-Smith being discharged on 4 January 1940. In January 1942, after a brief editorial job with the newsletter of the Communist-led Canadian Seamen's Union, he walked away from the Party and all political activity for good. He died in 1963 (227-228).

Discounting memoirs, popular histories and the sub-genre of literature concerning Dr. Norman Bethune, prior to Not for King or Country, only two books on the subject of Canadians in the Spanish Civil War could be considered scholarly. Victor Hoar's The Mackenzie-Papinean Battalion: Canadian Participation in the Spanish Civil War and Michael Petrou's Renegades: Canadians in the Spanish Civil War are generations apart. Hoar's work largely rests on the massive collection of oral histories of Canadian veterans of Spain compiled by CBC Radio in the mid-1960s. Petrou's book, published long after the opening of former Soviet archives, relies heavily on documents from the International Brigades released through the Russian State Archive of Socio-Political History. While Hoar celebrates the volunteers, Petrou provides a more critical account of a group he often sees as lacking in discipline. Wentzell steers a middle course. In his introduction he advises his readers, "[it] is important to approach the subject with some political agnosticism and a detached historical sensitivity" (6). In this, he is successful. While always remaining respectful in tone towards both Cecil-Smith and other Canadian volunteers, he never falls into hagiography. Using the same former Soviet fonds as Petrou, it is surprising that he barely touches the oral history collection used so well by Hoar. Surely the men CecilSmith commanded had opinions of their leader. Wentzell does make extensive use 
of RCMP files, including Cecil-Smith's rather extensive one, as well as a personal interview he conducted with Cecil-Smith's son Bill in 2018.

The book's greatest strength is its attention to Cecil-Smith as a theatre worker on behalf of the Party. Aside from retired professor of English and theatre studies Alan Filwod's Committing Theatre: Theatre Radicalism and Political Intervention in Canada, very little has been published regarding the Party's cultural activism. For this reason, Wentzell is to be congratulated for his linkage of theatre and workingclass struggle. It is surprising, therefore, that the author has not availed himself of the Toby Gordon Ryan Collection at the University of Guelph, the only archival fonds in existence concerning the Party's cultural activism. However, the photo section of the book includes an image of the final scene of the play Eight Men Speak credited to this collection, suggesting that although the author accessed the collection, the only content he found useful was a single photograph.

Not for King or Country is not without criticism. One is the degree of detail given to the military aspects of the book in the section on Spain. While revealing the author's background as an infantry officer, it detracts from the biographical and socio-political nature of the work. Secondly, its ending is abrupt. The period of 1940 to Cecil-Smith's death in 1963 is barely mentioned. Granted Wentzell is most concerned with his subject's political activism, as a biography it is incomplete. There are also stylistic issues. One of these is the absence of punctuation for Spanish place names and people. Omission of tildes and accents do result in spelling errors. Related to this is the plethora of typographical errors throughout the text, although in fairness the University of Toronto Press must take responsibility for this.

Not for King or Country is a welcome scholarly addition to the literature concerning the activities of the Communist Party of Canada during the 1930s. Wentzell employs Cecil-Smith first as a witness to the savage suppression of legitimate working-class dissent channeled through the Communist Party, and then as an agent himself of such dissent, especially on the cultural front. His willingness to put himself in harm's way to fight fascism, being wounded twice, and then returning to Canada to don another uniform to continue the fight demonstrates not only Cecil-Smith's convictions, but his courage. 